\title{
PENGARUH PENGGUNAAN MULTIMEDIA ANIMASI PADA PEMBELAJARAN KOMPETENSI DASAR MEMPERBAIKI SISTEM STARTER TERHADAP PENINGKATAN HASIL BELAJAR SISWA SMK
}

\author{
Hery Maksudi ${ }^{1}$, Ono Wiharna ${ }^{2}$, Dedi Rohendi ${ }^{3}$ \\ Departemen Pendidikan Teknik Mesin \\ Universitas Pendidikan Indonesia \\ Jl. Dr. Setiabudhi No. 207 Bandung 40154 \\ hery.maksudi@gmail.com
}

\begin{abstract}
ABSTRAK
Tujuan penelitian ini adalah untuk mengetahui hasil belajar siswa pada kompetensi dasar memperbaiki sistem starter dengan menggunakan multimedia animasi, mengetahui hasil belajar siswa pada kompetensi dasar memperbaiki sistem starter dengan menggunakan media visual gambar diam dan mengetahui peningkatan hasil belajar siswa yang menggunakan multimedia animasi dengan siswa yang menggunakan media visual gambar diam. Penelitian ini dilakukan menggunakan metode quasi experiment dengan desain penelitian non-equivalent control group design. Populasi dalam penelitian ini adalah siswa kelas XI TKR yang berjumlah 7 kelas dengan jumlah siswa 216 orang. Sampel penelitian ini diambil sebanyak dua kelas, yaitu kelas yang menggunakan multimedia animasi dan kelas yang menggunakan media visual gambar diam. Instrumen yang digunakan pada penelitian ini berupa soal pre test dan soal post test. Hasil pengolahan data penelitian ini diperoleh rata-rata hasil belajar siswa pada skor post test setelah menggunakan pembelajaran dengan multimedia animasi sebesar 83,54 dan rata-rata hasil belajar siswa pada skor post test setelah menggunakan pembelajaran dengan media visual gambar diam sebesar 72,80. Peningkatan hasil belajar siswa ( $N$-Gain) yang menggunakan pembelajaran dengan multimedia animasi sebesar 0,67 , sedangkan peningkatan hasil belajar siswa ( $N$-Gain) yang menggunakan pembelajaran dengan media visual gambar diam sebesar 0,41. Kesimpulan penelitian ini bahwa peningkatan hasil belajar siswa yang menggunakan multimedia animasi lebih baik dari pada siswa yang menggunakan media visual gambar diam.
\end{abstract}

Kata kunci: multimedia, animasi, hasil belajar, kompetensi, media visual

\section{PENDAHULUAN}

Pendidikan merupakan suatu proses pembinaan, pengayoman, pengajaran dan pembentukan karakter manusia atau siswa, baik fisik dan mental untuk mencapai suatu tujuan. Tujuan pendidikan yang harus dicapai pada hakikatnya merupakan bentuk-bentuk atau pola tingkah laku yang harus dikuasai oleh siswa, baik pengetahuan, sikap, maupun keterampilan. Pengetahuan, sikap, maupun keterampilan dapat diperoleh siswa dalam lembaga pendidikan melalui suatu proses pembelajaran (Djamarah, 2008).

Pembelajaran merupakan proses interaksi dua arah, mengajar oleh guru sebagai pendidik dan belajar oleh siswa. Peran guru adalah mengarahkan dan memfasilitasi siswa belajar, agar siswa dapat dengan mudah menerima pelajaran yang disampaikan oleh guru dan terciptanya pembelajaran yang baik dan menghasilkan lulusan yang berkompeten di bidangnya.

\footnotetext{
${ }^{1}$ Mahasiswa Departemen Pendidikan Teknik Mesin FPTK UPI

2 Dosen Departemen Pendidikan Teknik Mesin FPTK UPI

${ }^{3}$ Dosen Departemen Pendidikan Teknik Mesin FPTK UPI
} 
Hasil belajar siswa dipengaruhi oleh beberapa faktor yang dikelompokkan menjadi 3 bagian yaitu raw input, environmental input dan instrumental input (Rusman, 2013). Faktor yang pertama adalah raw input yang meliputi minat, bakat, pengalaman, tingkat perkembangan dan tingkat kecerdasan siswa. Faktor kedua environmental input yang meliputi aturan kelas, waktu, iklim sekolah dan lingkungan sekolah. Faktor ketiga adalah instrumental input yang meliputi kurikulum, media pembelajaran, alat, bahan dan sebagainya.

Proses pembelajaran dapat berhasil dengan baik apabila siswa dapat memanfaatkan semua alat inderanya (Sadiman, 2008). Guru harus berupaya menampilkan rangsangan yang dapat diproses dengan berbagai indera. Semakin banyak alat indera yang dipergunakan untuk menerima dan mengolah informasi maka semakin besar kemungkinan informasi tersebut dimengerti. Siswa diharapkan dapat menerima dan menyerap dengan mudah dan baik materi pembelajaran yang disajikan, karena tugas guru bukan hanya mengajar namun harus bisa membuat siswa untuk belajar.

Berdasarkan data yang diperoleh dari 2 (dua) SMK Negeri di Bandung kompetensi dasar memperbaiki sistem starter merupakan salah satu pelajaran yang diajarkan pada siswa tingkat XI tahun ajaran 2014/2015. Data yang diperoleh untuk kompetensi dasar memperbaiki sistem starter menunjukan bahwa hasil belajar siswa masih rendah dan distribusinya pun tidak merata 57\% siswa mendapat nilai kurang dan tidak memenuhi KKM. Alasan yang menjadi sorotan adalah pada aspek kognitif dimana para siswa kesulitan dalam memahami nama komponen, fungsi komponen dan proses kerja dari sistem starter. Kesulitan muncul karena keseluruhan materi motor starter berhubungan dengan kelistrikan dimana arus listrik tidak bisa dilihat secara langsung secara visual.

Karakteristik dari kompetensi dasar memperbaiki sistem starter adalah pemahaman terhadap komponen, fungsi dan cara kerja sistem. Proses pembelajaran dari sistem starter selain dilaksanakan dengan menggunakan model pembelajaran Inquiry Based Learning (IBL), Discovery Based Learning (DBL), Project Based Learning (PjBL) dan Problem Based Learning oleh guru dijelaskan juga dengan bantuan dalam bentuk gambar komponen dan wiring diagram yang merupakan salah satu dari jenis media pembelajaran (Munir, 2012).

Media pembelajaran merupakan salah satu unsur dari instrumental input dalam kegiatan belajar mengajar dimana sangat berpengaruh terhadap pemahaman siswa untuk memahami komponen, fungsi dan cara kerja sistem (Grivin, 2009). Media pembelajaran yang diterapkan di SMK Negeri di Bandung untuk kompetensi dasar memperbaiki sistem starter saat ini masih menggunakan media pembelajaran visual berupa gambar diam. Media 
pembelajaran dengan gambar diam kurang cocok untuk menyampaikan isi materi dari kerja sistem starter yang didalamnya bersangkutan dengan kelistrikan berupa gerak arus listrik, secara nyata gerak arus listrik tidak dapat terlihat. Hal ini membuat siswa tidak dapat menggambarkan secara jelas isi materi yang disampaikan sehingga terjadi perbedaan persepsi dari setiap siswa.

Mengatasi masalah perbedaan dalam menjelaskan materi sistem starter dapat dicoba dengan merubah yang awalnya menggunakan media pembelajaran media visual gambar diam, dirubah dengan menggunakan media pembelajaran berbasis multimedia animasi. Perubahaan dari media visual gambar diam ke multimedia animasi ini diharapkan setiap siswa dapat menyamakan persepsi untuk penjelasan isi materi yang disampaikan oleh guru (Suheri, 2006).

Salah satu media pembelajaran jenis audio visual gerak adalah media multimedia animasi yang terdiri dari beberapa media yang terintegerasi, antara lain: gambar, suara, animasi dan tulisan. Penerapan multimedia animasi ini terhadap proses pembelajaran mempunyai kelebihan dalam memperjelas penyajian pesan pembelajaran selain itu lebih efektif dan efisien dalam penggunaannya terhadap kompetensi dasar memperbaiki sistem starter (Nugroho , 2011). Penggunaan multimedia animasi ini juga dapat menghemat waktu maupun biaya dalam proses pembelajaran namun multimedia animasi ini juga masih mengacu pada tujuan pembelajaran.

\section{METODE PENELITIAN}

Metode yang digunakan dalam penelitian ini adalah metode kuasi eksperimen (Quasi Exsperimental Design). Selama melakukan eksperimen, siswa merupakan objek penelitian yang tetap mengikuti pelajaran dalam kelas seperti biasa. Selain itu, pemilihan objek penelitian juga tidak dilakukan secara acak.

Desain penelitian yang digunakan dalam penelitian ini adalah (Nonequivalent Control Group Design). Desain ini hampir sama dengan pre test-post test grup design, hanya pada design ini kelompok eksperimen maupun kelompok kontrol tidak dipilih secara random. Desain penelitian ini menempatkan subjek penelitian ke dalam dua kelompok kelas yang terdiri dari kelompok eksperimen dan kelompok kontrol yang tidak dipilih secara acak.

\section{HASIL PENELITIAN}

Hasil uji normalitas dengan SPSS 20.0 menggunakan metode Lilliefors dan Shapiro Wilk. Nilai Sig ( $p$-value $)<0,05$ berarti data tidak berdistribusi normal. Hasil uji homogenitas 
menggunakan metode Levene's test. Uji Levene lebih dianjurkan dikarenakan uji tersebut dapat digunakan untuk menguji homogenitas varians pada data yang tidak berdistribusi normal. Nilai uji Levene's Test ditunjukkan pada baris nilai based on mean, yaitu dengan Sig ( $p$ - value) $1.194>0,05$ yang berarti varians kedua kelompok sama atau yang disebut homogen. Mean rank atau rata-rata peringkat tiap kelompok. Kelas kontrol dengan rerata peringkatnya 20,40 lebih rendah dari pada rerata kelas eksperimen, yaitu 30,60. Nilai U sebesar 163.5 dan nilai $\mathrm{W}$ sebesar 793.5. Apabila dikonversikan ke nilai Z maka besarnya 5.332. Nilai Sig atau $p$-value sebesar $0,000<0,05$. Apabila nilai $p$-value $<$ batas kritis 0,05 maka terdapat perbedaan signifikan antara dua kelompok atau yang berarti $\mathrm{H} 1$ diterima.

\section{PEMBAHASAN}

Hasil belajar siswa dapat diperoleh setelah melakukan proses pembelajaran yang di ukur melalui tes, tes ini dilakukan dua kali yang pertama pre test (tes sebelum melakukan pembelajaran) dan post test (tes setelah melakukan proses pembelajaran). Post test diambil sebagai hasil belajar siswa. Kemampuan awal siswa sebelum melakukan proses pembelajaran tidak ada perbedaan yang signifikan kemampuan awal siswa sebelum menerima materi pembelajaran antara kelas eksperimen dan kelas kontrol. Terbukti dengan data pre test yang menunjukkan bahwa kedua kelas tersebut homogen namun hasil belajar siswa masih dalam interpretasi sangat kurang atau masih di bawah KKM (Sukiyasa, 2013).

Peningkatan yang signifikan terlihat pada hasil post test yang dilaksanakan setelah proses pembelajaran. Nilai rata-rata post test siswa kelas eksperimen yang menggunakan multimedia animasi lebih tinggi dibandingkan nilai rata-rata post test kelas kontrol yang menggunakan media visual gambar diam. Nilai rata-rata post test kelas eksperimen berada pada interpretasi cukup sedangkan kelas kontrol berada pada interpretasi kurang. Rata-rata peningkatan hasil belajar siswa kelas eksperimen yang menggunakan multimedia animasi lebih tinggi dibandingkan dengan rata-rata peningkatan hasil belajar siswa kelas kontrol yang menggunakan media visual gambar diam (Asyhar, 2012). Terbukti dengan uji hipotesis penelitian, yaitu peningkatan hasil belajar siswa yang menggunakan multimedia animasi lebih baik dibandingkan siswa yang menggunakan gambar gambar visual diam.

Penggunaan multimedia animasi pada kompetensi perbaikan differensial ternyata memberikan pengaruh yang sangat besar terhadap peningkatan hasil belajar siswa hali ini dikarenakan multimedia ini mampu menampilkan materi-materi motor starter. Mampu menampilkan objek-objek yang sebenarnya tidak ada secara fisik atau diistilahkan dengan 
imagery. Secara kognitif pembelajaran dengan menggunakan mental imagery akan meningkatkan retensi siswa dalam mengingat materi-materi pelajaran (Munadi, 2013).

Hal ini karena siswa langsung berinteraksi dan juga adanya tayangan menarik juga adanya animasi dapat membuat siswa tertarik untuk belajar materi pelajaran yang diberikan. Pemakaian media pembelajaran dalam proses belajar dapat membangkitkan keinginan dan minat yang baru, membangkitkan motivasi dan rangsangan kegiatan belajar, dan bahkan membawa pengaruh psikologis terhadap siswa (Arsyad, 2010).

Hasil penelitian dapat memberikan gambaran bahwa penggunaan multimedia animasi dapat dijadikan media pembelajaran yang dapat membantu meningkatkan pemahaman siswa menjadi lebih baik. Bila yang diajarkan adalah suatu proses, maka media gerak seperti video, animasi, film atau televisi merupakan pilihan yang sesuai (Wibawa, Basuki dan Mukti, 1991). Multimedia interaktif banyak sekali memiliki kelebihan terutama dengan tampilan yang menarik bagi siswa sehingga dengan ini siswa dapat lebih terangsang untuk dapat mempelajari materi pelajaran yang disampaikan.

\section{KESIMPULAN}

Penelitian ini dapat disimpulkan bahwa hasil belajar siswa pada kompetensi dasar memperbaiki sistem starter dengan menggunakan multimedia animasi meningkat secara signifikan. Hasil belajar siswa pada kompetensi dasar memperbaiki sistem starter dengan menggunakan media visual berupa gambar diam meningkat tetapi tidak terlalu signifikan. Peningkatan hasil belajar siswa yang menggunakan multimedia animasi lebih baik dari pada siswa yang menggunakan media visual gambar diam.

\section{DAFTAR PUSTAKA}

Arsyad, A. (2010). Media pembelajaran. Jakarta : PT. Raja Grafindo Persada.

Asyhar, R. (2012). Kreatif Mengembangkan Media Pembelajaran. Jakarta: Referensi.

Djamarah, S.B. (2008). Strategi Belajar Mengajar. Jakarta: Rineka Cipta.

Grivin M. W. (2009). Animasi dalam Media Pembelajaran. Jurnal Animasi Multimedia Pembelajaran, (1), 1-5.

Munadi, Y. (2013). Media Pembelajaran. Jakarta: Referensi.

Munir. (2012). Multimedia: Konsep dan Aplikasi dalam pendidikan. Bandung: Alfabeta. 
Nugroho P. S. (2011). Perancangan Media Pembelajaran Berbasis Multimedia Untuk DasarDasar Pembuatan Animasi 2D Menggunakan Macromedia Flash MX 2004. Jurnal Dasi 12. (2), 50-53.

Rusman. (2013). Belajar dan Pembelajaran Berbasis Komputer. Bandung: Alfabeta.

Sadiman, A. (2012). Media Pendidikan. Jakarta: PT. Raja Grafindo Persada.

Suheri, A (2006). Animasi Media Pembelajaran. Jurnal Animasi Multimedia Pembelajaran. $2,(1), 27-33$.

Sukiyasa K. (2013). Pengaruh Media Animasi terhadap Hasil Belajar dan Motivasi Belajar Siswa Materi Sistem Kelistrikan Otomotif. Jurnal Pendidikan Vokasi. 3, (1), 126-137.

Wibawa, Basuki \& Mukti, F. (1991). Media Pengajaran. Jakarta: Departemen Pendidikan dan Kebudayaan Direktorat Jendral Pendidikan Tinggi Proyek Pembinaan Tenaga Kependidikan. 